\title{
Effect of sillimanite beach sand composition on mullitization and properties of $\mathrm{Al}_{2} \mathrm{O}_{3}-\mathrm{SiO}_{2}$ system
}

\author{
H S TRIPATHI*, B MUKHERJEE, S K DAS, A GHOSH and G BANERJEE \\ Refractories Division, Central Glass and Ceramic Research Institute, Kolkata 700 032, India \\ MS received 26 February 2001; revised 1 April 2002
}

\begin{abstract}
Mullite was developed by reaction sintering of sillimanite beach sand and calcined alumina. Two varieties of sillimanite beach sand viz. $S$ and $Z$ having different compositions were selected. Synthesis and properties of mullite were very much dependent on the sillimanite beach sand composition. Presence of higher amount of impurities in the $\mathrm{Z}$-variety of sillimanite sand favours the densification by liquid phase formation. Presence of zircon in Z-variety increases the hardness and fracture toughness. Alumina addition improves the mechanical/thermomechanical properties of the samples. Mullite retains the usual orthorhombic habit of sillimanite. Rounded to sub rounded zirconia dispersed within the mullite matrix of the sample ZA is noticed.
\end{abstract}

Keywords. Sillimanite; mullite; beach sand; aggregate.

\section{Introduction}

Beach sand minerals did not gain so much importance till their counterpart rock minerals were available in abundance at an affordable price. With the depletion of rock minerals, demands for technology have gone up that would convert these minerals into value added products (Banerjee 1998; Tripathi and Banerjee 1998, 1999). In the $\mathrm{Al}_{2} \mathrm{O}_{3}-\mathrm{SiO}_{2}$ system, the importance of mullite is well known for a long time. Stoichiometric mullite has a $3: 2$ molar ratio of $\mathrm{Al}_{2} \mathrm{O}_{3} / \mathrm{SiO}_{2}$. It has (i) low thermal expansion, (ii) low thermal conductivity, (iii) excellent creep resistance, (iv) good chemical stability and (v) high oxidation resistance.

Generally mullite is occasionally found in nature, as its formation need high temperature and low pressure conditions. Sillimanite which is $\mathrm{Al}_{2} \mathrm{O}_{3} \cdot \mathrm{SiO}_{2}$, occurred in nature in rock form. But the rock form sillimanite has been depleted/exhausted in many parts of the world. Placer deposits of beach sand sillimanite minerals occur in a number of coastal areas. Placer deposits are of two types, viz. beach placers and inland placers.

In India, sillimanite beach placer deposits are found in the eastern and southern coasts (Nagar 1995). In the present investigation, two varieties of sillimanite beach sand were selected. Efforts have been made to study the effect of sand composition on the mullitization and properties of the aggregates.

\section{Experimental}

Sillimanite beach sand was obtained from Indian Rare Earths Limited from two different regions (S-variety and

*Author for correspondence
$\mathbf{Z}$-variety). $\mathbf{S}$-variety and $\mathbf{Z}$-variety of sillimanite were obtained from the eastern coast of Orissa and southern coast of Tamilnadu, respectively. Calcined alumina was obtained from the Indian Aluminium Company Limited, India. Batches were prepared with the above raw materials as well as by the addition of $\mathrm{Al}_{2} \mathrm{O}_{3}$ to convert the $\mathrm{SiO}_{2}$ available into mullite as shown in table 1 .

Batches were mixed and milled in a $750 \mathrm{cc}$ attritor mill in water medium for $5 \mathrm{~h}$. The ratio of charge to grinding media was maintained at $1: 7$. Slurries thus obtained were dried at $110 \pm 5^{\circ} \mathrm{C}$ for $24 \mathrm{~h}$, crushed to break the agglomerate, mixed with 5\% PVA solution as binder and pressed into shapes. Rectangular bars of $60 \times 60 \times 6 \mathrm{~mm}$ were initially uniaxially pressed at $100 \mathrm{MPa}$ and then isostatically pressed at $175 \mathrm{MPa}$. Bars were sintered in air at 1500,1550 , and $1600^{\circ} \mathrm{C}$ with $2 \mathrm{~h}$ soaking time. Sintering was done in an electrically heated furnace and the heating rate was maintained at $5^{\circ} \mathrm{C} / \mathrm{min}$. Sintered products thus obtained were characterized in terms of bulk density, apparent porosity, mechanical and thermomechanical properties and microstructure. Apparent porosity and bulk density of the samples were measured by conventional water displacement method using Archimedes' principle.

High temperature flexural strength of the samples were measured at $1200^{\circ} \mathrm{C}$ by standard 3-point bending method. Samples which were sintered at $1600^{\circ} \mathrm{C}$ for $2 \mathrm{~h}$ were used to measure Young's modulus, hardness and fracture toughness. Young's modulus was measured by nondestructive Sonic method. Hardness and fracture toughness of samples were measured through Vickers' indentation using a load of 49 N. X-ray powder diffraction pattern of the raw materials and fired products were obtained in an X-ray diffractometer using nickel filtered $\mathrm{Cu}-\mathrm{K} \alpha$ radiation. Diffraction patterns were recorded in the Braggs angle $2 \theta$ 
range $10-55^{\circ}$. Microstructural analysis was done by scanning electron microscopy (SEM) using sputtered gold coating on fracture surface of the sintered samples.

\section{Results and discussion}

Chemical analysis of the raw materials are given in table 2 . From table 2 it is seen that, the amount of $\mathrm{ZrO}_{2}, \mathrm{TiO}_{2}$ and alkali present in the $\mathbf{S}$ and $\mathbf{Z}$-varieties of sillimanite sand differ significantly. Both the sillimanite sands contain higher amount of silica than the stoichiometric amount. It was found that $\mathbf{Z}$-variety contains $\mathrm{ZrO}_{2}$ in the form of zircon (Banerjee 1998).

\subsection{Densification}

Degree of densification can be evaluated by means of bulk density of the sintered samples. Variation of bulk density with the sintering temperature is shown in figure 1. It is seen that sample $\mathbf{Z}$ achieved its highest bulk density of $3.04 \mathrm{~g} / \mathrm{cc}$ at a sintering temperature of $1550^{\circ} \mathrm{C}$ (apparent porosity, $0.49 \%$ ), whereas the sample $\mathbf{S}$ requires a temperature of $1600^{\circ} \mathrm{C}$ to achieve its highest bulk density. Alumina addition in the batch $(\mathbf{S A}$ and $\mathbf{Z A})$ requires higher sintering temperature for the same level of densification. At $1600^{\circ} \mathrm{C}$ the bulk density of $\mathbf{S A}$ and $\mathbf{Z A}$ is higher compared to respective alumina free samples $(\mathbf{S}$ and $\mathbf{Z})$ due to the higher $\mathrm{Al}_{2} \mathrm{O}_{3}$ content. Apparent porosity of the $\mathbf{Z}$ samples sintered at $1500^{\circ} \mathrm{C}$ is $3.90 \%$ which is significantly lower compared to that of $\mathbf{S}$ sample (19.65\%).

Table 1. Batch composition and sample code used for the study.

\begin{tabular}{lccc}
\hline & \multicolumn{2}{c}{ Sillimanite beach sand (wt $\%)$} & $\begin{array}{c}\text { Calcined alumina } \\
\text { (wt } \%)\end{array}$ \\
\cline { 2 - 4 } Sample code & S-variety & Z-variety & Nil \\
\hline S & $100 \cdot 00$ & Nil & $31 \cdot 03$ \\
SA & 68.97 & Nil & Nil \\
Z & Nil & $100 \cdot 00$ & $27 \cdot 00$ \\
ZA & Nil & 73.00 & \\
\hline
\end{tabular}

Table 2. Chemical analysis of the raw materials.

\begin{tabular}{lccc}
\hline \multirow{2}{*}{$\begin{array}{l}\text { Constituents } \\
\text { (wt\%) }\end{array}$} & \multicolumn{2}{c}{ Sillimanite beach sand } & \\
\cline { 2 - 3 } & S-variety & Z-variety & Calcined alumina \\
\hline $\mathrm{SiO}_{2}$ & $40 \cdot 30$ & 35.45 & \\
$\mathrm{Al}_{2} \mathrm{O}_{3}$ & 57.60 & 53.27 & 99.3 \\
$\mathrm{Fe}_{2} \mathrm{O}_{3}$ & 0.31 & 0.65 & \\
$\mathrm{TiO}_{2}$ & $0 \cdot 11$ & 2.25 & \\
$\mathrm{ZrO}_{2}$ & - & 6.40 & \\
$\mathrm{CaO}$ & 0.42 & 0.51 & \\
$\mathrm{MgO}$ & 0.31 & - & \\
$\mathrm{K}_{2} \mathrm{O}+\mathrm{Na}_{2} \mathrm{O}$ & 0.02 & 0.15 & 0.3 \\
L.O.I & 0.70 & 0.85 & \\
\hline
\end{tabular}

This is due to the presence of higher amount of alkali in sample $\mathbf{Z}$ which reduces the porosity by means of glass formation. Bulk density of all the samples except $\mathbf{Z}$ increases with sintering temperature up to $1600^{\circ} \mathrm{C}$ since $\mathbf{Z}$ has higher amount of impurities which help in liquid phase sintering at a lower temperature. In case of $\mathbf{Z}$, bulk density reaches a maximum value of $3.04 \mathrm{~g} / \mathrm{cc}$ at $1550^{\circ} \mathrm{C}$ and falls subsequently at $1600^{\circ} \mathrm{C}$. $\mathbf{Z}$ has nearly eight times the alkali content than that of $\mathbf{S}$ sample. Its $\mathrm{Fe}_{2} \mathrm{O}_{3}$ and $\mathrm{TiO}_{2}$ contents are two and twenty one times more, respectively than that of $\mathbf{S}$. This results in the formation of excessive amount of glass, which is responsible for low BD of the sample $\mathbf{Z}$ sintered at $1600^{\circ} \mathrm{C}$.

\subsection{Mechanical properties}

High temperature flexural strength is an important parameter for refractories selection. The high temperature strength of the refractory aggregates depends on the porosity, grain size, amount and nature of glassy phase. Variation of hot $\mathrm{MOR}$ at $1200^{\circ} \mathrm{C}$ of the samples with sintering temperature is depicted in figure 2. It is seen that, HMOR of the samples $\mathbf{S}$ and $\mathbf{Z}$ are primarily

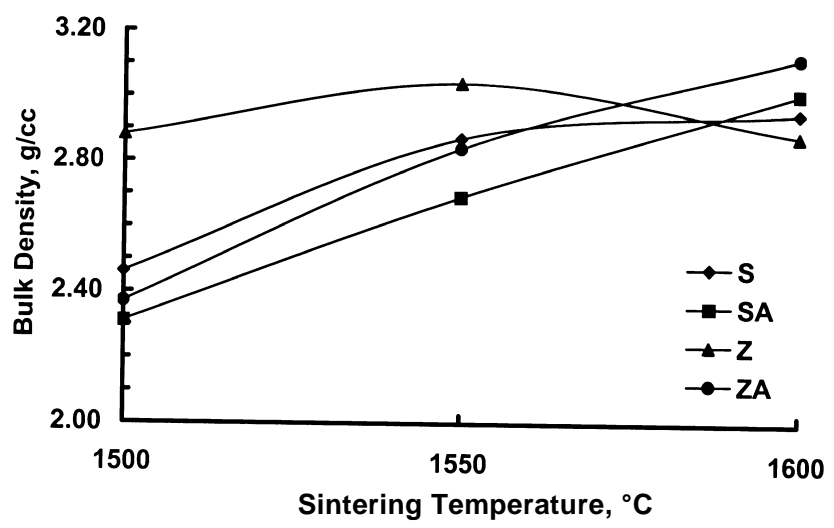

Figure 1. Variation of bulk density with sintering temperature.

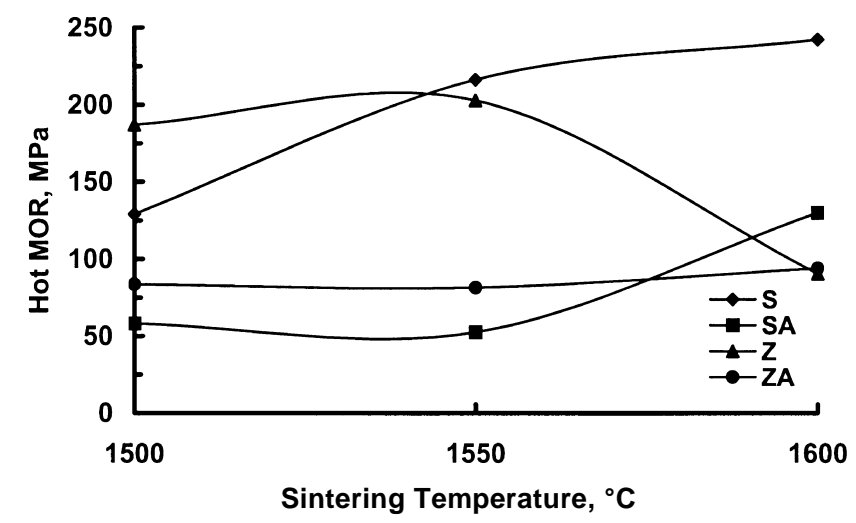

Figure 2. Variation of hot $\mathrm{MOR}$ at $1200^{\circ} \mathrm{C}$ with sintering temperature. 
dependent on their densification. Once densification with $<1 \%$ porosity is achieved, the amount and nature of glassy matrix becomes the determining factor of HMOR. At the sintering temperature of $1600^{\circ} \mathrm{C}$, the hot MOR of sample $\mathbf{S}$ is $242.4 \mathrm{MPa}$ compared to only $90.5 \mathrm{MPa}$ for that of sample $\mathbf{Z}$. The presence of higher amount of low melting glassy phase due to the impurities present in the raw material of sample $\mathbf{Z}$ is responsible for its low hot MOR values. At any sintering temperature the hot MOR of alumina containing samples (SA and $\mathbf{Z A})$ are lower compared to alumina free samples ( $\mathbf{S}$ and $\mathbf{Z}$ ) due to the presence of higher amount of high silica glass in the latter samples. At $1200^{\circ} \mathrm{C}$, the softening of high silica glassy phase and subsequent stress relaxation at the crack tips is responsible for higher hot MOR values of $\mathbf{S}$ and $\mathbf{Z}$ containing higher amount of $\mathrm{SiO}_{2}$ (Osendi and Baudin 1996).

Table 3. Young's modulus, hardness and fracture toughness of the samples sintered at $1600^{\circ} \mathrm{C}$.

\begin{tabular}{lccc}
\hline Sample & $\begin{array}{c}\text { Young's modulus } \\
(\mathrm{GPa})\end{array}$ & $\begin{array}{c}\text { Hardness } \\
(\mathrm{GPa})\end{array}$ & $\begin{array}{c}\text { Fracture } \\
\text { toughness } \\
\left(\mathrm{MPa}^{-1 / 2}\right)\end{array}$ \\
\hline $\mathbf{S}$ & 160 & $9 \cdot 33$ & $1 \cdot 90$ \\
$\mathbf{Z}$ & 160 & $9 \cdot 28$ & $2 \cdot 20$ \\
SA & 203 & $10 \cdot 93$ & $2 \cdot 18$ \\
ZA & 176 & $8 \cdot 25$ & $2 \cdot 58$ \\
\hline
\end{tabular}

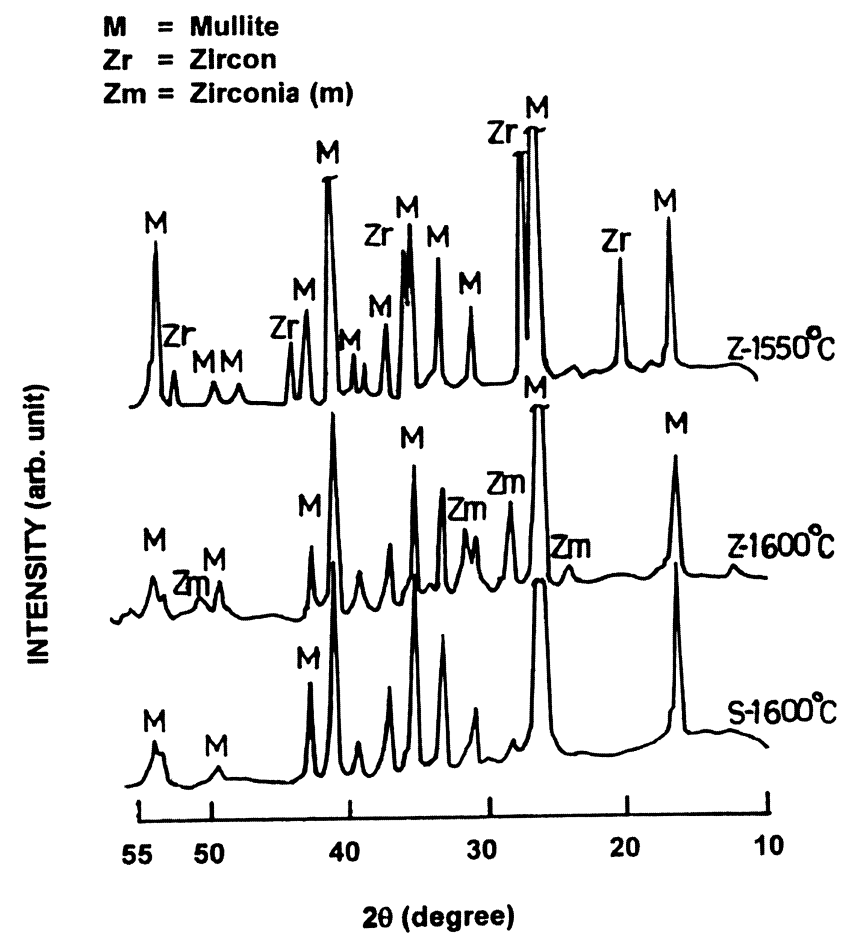

Figure 3. X-ray diffraction pattern $(\mathrm{CuK} \alpha)$ of the sintered samples (sample code with sintering temperature are shown).
Young's modulus, hardness and fracture toughness of the samples sintered at $1600^{\circ} \mathrm{C}$ are given in table 3 . All the samples show a moderate level of Young's modulus and hardness. Samples $\mathbf{Z}$ and $\mathbf{Z A}$ exhibit higher fracture toughness than that of samples $\mathbf{S}$ and $\mathbf{S A}$, respectively. The presence of $\mathrm{ZrO}_{2}$ in $\mathbf{Z}$ and $\mathbf{Z A}$ contributed to the higher fracture toughness of these materials. The addition of $\mathrm{Al}_{2} \mathrm{O}_{3}$ to the batch improved the Young's modulus and fracture toughness of the materials due to higher amount of mullite formation.

\subsection{Microstructure}

X-ray diffraction pattern of some sintered samples are shown in figure 3 . It is seen that the main crystalline phase present in all the samples is mullite. Sample $\mathbf{Z}$, which has been sintered at $1550^{\circ} \mathrm{C}$ still has zircon phase present. Whereas the same sample sintered at $1600^{\circ} \mathrm{C}$ shows that the zircon has decomposed into zirconia and silica. Zirconia mostly occurs in monoclinic form. Scanning electron photomicrograph of the samples $\mathbf{S A}$ and $\mathbf{Z A}$
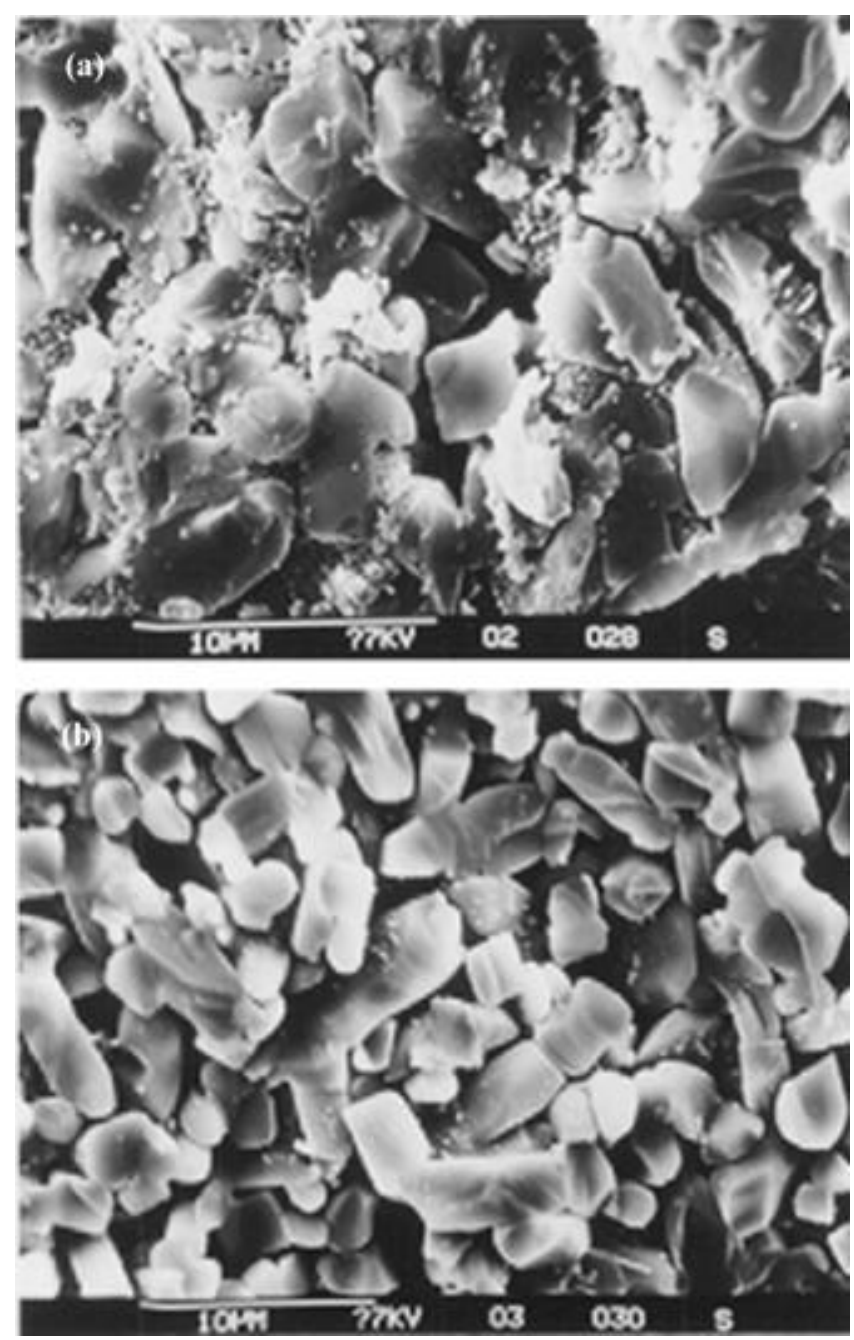

Figure 4. Scanning electron photomicrograph of the samples sintered at $1600^{\circ} \mathrm{C}$ : a. SA and b. ZA. 
sintered at $1600^{\circ} \mathrm{C}$ are shown in figures $4 \mathrm{a}-\mathrm{b}$. Mullite formed in the above samples retains the orthorhombic habit of sillimanite. Mullite crystals are interlocked with each other. Small amount of rounded to sub rounded $\mathrm{ZrO}_{2}$ embedded in the mullite matrix is noticed in sample $\mathbf{Z A}$ (figure $4 b$ ). Zirconia present in the sample $\mathbf{Z A}$ is in the monoclinic form. $\mathrm{ZrO}_{2}$ occupies both intergranular and intragranular positions within the mullite matrix. Presence of zirconia in $\mathbf{Z A}$ possibly reduces the amount of intergranular vitreous phases and mullite grain growth compared to sample $\mathbf{S A}$ as can be seen from the microstructure.

\section{Conclusions}

Synthesis and mechanical properties of mullite developed from sillimanite beach sand is very much dependent on the sillimanite sand composition. $\mathbf{Z}$-variety sillimanite sand containing higher amount of impurities densifies at lower temperature through liquid phase sintering. $\mathrm{ZrO}_{2}$ reduces the grain growth of the mullite which is formed in situ. Alumina addition always lower the hot MOR at $1200^{\circ} \mathrm{C}$ due to the reduction of high silica glass content.

\section{References}

Banerjee G 1998 Bull. Mater. Sci. 21349

Nagar M S 1995 J. Mines, Metals \& Fuels XLII 376

Osendi M I and Baudin C 1996 J. Eur. Ceram. Soc. 16217

Tripathi H S and Banerjee G 1998 J. Eur. Ceram. Soc. 18 2081

Tripathi H S and Banerjee G 1999 Ceram. Int. 2519 